\title{
ENTREPRENEURSHIP AND ECONOMIC TRANSITION IN CENTRAL EUROPE
}


Jean-Paul Larçon

Editor

\section{ENTREPRENEURSHIP AND ECONOMIC TRANSITION IN CENTRAL EUROPE}

Springer Science+Business Media, LLC 


\section{Library of Congress Cataloging-in-Publication Data}

Entrepreneurship and economic transition in Central Europe / Jean-Paul

Larçon editor.

$$
\text { p. } \mathrm{cm} \text {. }
$$

Includes bibliographical references (p. ) and index.

ISBN 978-1-4613-7941-6 ISBN 978-1-4615-6401-0 (eBook)

DOI 10.1007/978-1-4615-6401-0

1. Structural adjustment (Economic Policy)--Europe, Central.

2. Europe, Central--Economic conditions. 3. Privatization--Europe,

Central. 4. Entrepreneurship--Europe, Central. I. Larçon, Jean-

Paul.

HC244.E57 1998

98-39133

338.943--dc21

CIP

Copyright (C) 1998 by Springer Science+Business Media New York Originally published by Kluwer Academic Publishers, New York in 1998 Softcover reprint of the hardcover 1st edition 1998

All rights reserved. No part of this publication may be reproduced, stored in a retrieval system or transmitted in any form or by any means, mechanical, photocopying, recording, or otherwise, without the prior written permission of the publisher, Springer Science+Business Media, LLC.

Photograph Copyright - "Roger-Viollet"

Technical Support - "Tessier-Ashpool, Ltd."

Printed on acid-free paper. 
To my daughter Anne-Sophie 


\section{Contents}

Contributors $\quad$ xi

Preface and Acknowledgements $\quad$ xv

Introduction: Organisation of the Book xix

Abbreviations $\quad$ xxiii

1 Business Strategies for Economies in Transition

of Central and Eastern Europe

Jean-Paul Larçon

Return to Europe

From plan to market: privatisation

New economic and social environment

Foreign trade and Foreign Direct Investment 8

Strategies of international companies 11

Conclusions $\quad 16$

$\begin{array}{ll}\text { Notes } & 18\end{array}$

$\begin{array}{ll}\text { References } & 18\end{array}$

2 Privatisation and Company Restructuring in

Central and Eastern Europe: Issues and Progress 21

Saul Estrin

Why privatise at all? 22

Who will own the firms?

A taxonomy of mass privatisation $\quad 30$

Ownership structure in Central and Eastern Europe 32 
Conclusions $\quad 34$

References $\quad 35$

3 Lessons from Czech Privatisation 37

Ingeborg Nemcova

Privatisation as a key to transformation $\quad 37$

Privatisation forms and methods $\quad 40$

Present dilemmas and perspectives $\quad 51$

Notes $\quad 53$

References $\quad 53$

Appendix $\quad 55$

4 Development of Financial Markets: the Czech Case 57

Petr Musilek

The financial market revival $\quad 57$

Public markets $\quad 60$

Czech Stock Price Behaviour 66

Conclusion $\quad 69$

Notes $\quad 69$

$\begin{array}{ll}\text { References } & 70\end{array}$

5 Competitiveness and Industry Restructuring:

the Case of Hungary $\quad 71$

Attila Chikán and Erzsébet Czakó

Introduction 71

Microeconomic factors of competitiveness $\quad 72$

Seven main theses on competitiveness $\quad 89$

Conclusions $\quad 91$

References $\quad 92$

6 The Ethical Fabric of a Transformation Economy: the Case of Hungary 93

Laszlo Zsolnai

The social reception of market economy 94

Ethical attitudes of Hungarian Managers $\quad 98$

Ethicality of companies $\quad 99$

Prospects for the future 101

$\begin{array}{ll}\text { Notes } & 102\end{array}$

References 102 
7 Economic Growth and Foreign Direct Investment:

the Polish Case

Maria Romanowska

Investment attractiveness in Poland

Range and forms of foreign investors' presence in Poland $\quad 107$

Influence of Foreign Direct Investment on Polish economy 113

Conclusions

121

References

8 Transition and Democracy in Romania:

the Pain of a Gradualist Restructuring

Sergio Alessandrini

The economic and political legacy 126

$\begin{array}{ll}\text { The political developments } & 127\end{array}$

The economic performance and the structural changes 130

De-monopolisation and the private sector performance $\quad 134$

Economic policy reforms 135

External support and the role of FDI 143

The privatisation of SOEs in Romania 146

The economic and financial restructuring of industry 154

Agriculture

Foreign exchange controls affecting trading 157

Conclusions 158

$\begin{array}{ll}\text { Notes } & 160\end{array}$

References 161

9 Company Co-operations between

Eastern and Western Europe

Martin Zagler and Christian Ragacs

Reasons for macroeconomic analysis $\quad 163$

Analytical framework $\quad 165$

Innovation and strategic choices for SME 168

$\begin{array}{ll}\text { SME and development } & 169\end{array}$

Development and SME co-operation with Eastern Europe $\quad 170$

$\begin{array}{ll}\text { Conclusion } & 174\end{array}$

$\begin{array}{ll}\text { Notes } & 174\end{array}$

$\begin{array}{ll}\text { References } & 175\end{array}$ 
10 Swedish Multinationals in

Central and Eastern Europe

Jan-Erik Vahlne, Kjell A. Nordström and

Stryrbjörn Torbacke

The project

177

Objectives

Frame of Reference

Five cases on European Multinationals' entry

Tentative conclusions

References

11 The Enlargement Challenge

Franck Debié

Introduction

European governance and the enlargement challenge

Uncertain enlargement and challenges for corporate governance 203

Conclusion

210

References

Index 


\section{Contributors}

Sergio Alessandrini is Professor of Economics at the faculty of Law of the University of Modena. He is also Lecturer of European Political Economy at University L. Bocconi of Milano. In recent years he has carried out research on economic regionalism and European integration, with particular reference to the transition economies. He is a scientific advisor for the restructuring of the education system in Central European countries within Phare and Tacis programmes. Among his recent publications are: Economic Regionalism and World Trade System, Giuffrè editore, Milan, 1994, (with G. Sacerdoti) and The EU Foreign Direct Investments in Central and Eastern Europe, University L. Bocconi, July 1997.

Attila Chikan is Professor and Head of the Department of Business Economics at the Budapest University of Economic Sciences. He directed the research program the findings of which are presented in chapter 5 . He teaches Business Economics, Theories of the Firm and Management of the Value Creating Process. His special fields of interest include economic and business policy and the management of value creating process, focusing on manufacturing and logistics. He holds a number of national and international academic and business functions.

Erzsébet Czakó is Associate Professor and Deputy Head of the Department of Business Economics at the Budapest University of Economic Sciences. She was the Deputy Director of the research program the findings of which are presented in chapter 5. She teaches Business Economics and Strategic Management. Her special fields of interest are the content of and approaches to competitiveness researches, competitiveness of various sectors and higher education in business. 
Franck Debié is Assistant Professor in international management at HEC School of Management, Paris. Trained in history, geography and management, he has specialised in political and social sciences. His work is on peace processes, related political and economic transition and public governance. His fields of study are the Balkans and the Middle East. He teaches on political risk, international governance and European affairs in the HEC School of Management, the Ecole Normale Supérieure, Institut d'Etudes Politiques de Paris and Oxford University.

Saul Estrin joined the London Business School in 1991, where he is a Professor of Economics and head of the Economics subject area. He was formerly a Senior Lecturer at the London School of Economics, and has visited Cornell University, Stanford University and the University of Michigan Business School. His research concentrates on the process of economic reform and transformation in Central and Eastern Europe. He has particularly focused on questions of privatisation, company restructuring and different ownership forms.

Jean-Paul Larçon is Professor of Strategy at the HEC School of Management, Paris, where he teaches international strategic management. A former Dean of HEC and Professor Emeritus at Warsaw University of Technology school of business, he participates actively in the HEC research and educational programmes in Central Europe and the Community of Independent States. His current work focuses on business strategies in economies in transition.

Petr Musilek is the Deputy Head of the Banking and Insurance Department at the University of Economics, Prague (VSE Praha). A teacher of finance at VSE, he has also experience in the investment banking department of Bank Austria Vienna. He has published numerous books and articles focused primarily on the financial markets

Ingeborg Nemcova is Associate Professor at the department of Economic Policy, University of Economics, Prague (VSE Praha). She is an Engineer of Economics, Candidate of Science, and Alexander Hamilton fellow at USC, USA (1991-92). She teaches Economic Policy, Privatisation and Transformation at VSE and Charles University. She introduced Community of European Management Schools (CEMS) course of Economic Policy in Prague. She is the President of the Czech Fulbright alumni association.

Kjell A. Nordström is Assistant Professor at the Institute of International Business, Stockhom School of Economics, and Director of IIB education. His research concentrates on global competition, international strategy, the 
internationalisation processes and particularly the modes of involvement in Eastern Europe for corporations of advanced industrial countries.

Christian Ragacs is Assistant Professor at the Vienna University of Economics and Business Administration. He received the Theodor-Körner Price for his Contributions to Growth Policy in 1997. His fields of research are Theory of Economic Growth, Labour Economics, Theory of Income Distribution, History of Economic Theory in the 19th Century, Applied Econometrics, with an emphasis on Time Series Analysis.

Maria Romanowska is Professor at Warsaw School of Economics (Szkola Glowna Handlowa) and head of the Institute of Management. She is the author of many books on corporate strategy and strategic alliances. Her current research interest is in the process of concentration within Polish economy. The data base of the Institute of Management allows systematic monitoring of large Polish industrial groups: their behaviour and an analysis of the way they compete or co-operate with foreign companies in Poland.

Styrbjörn Torbacke, is a former research associate at the Institute of International Business of Stockolm School of Economics, is now the head of the computer department of Kraft-Freja in Stockholm.

Jan-Erik Vahlne is Professor of International Business and was formerly Rector of the Stockhom School of Economics in Riga, Latvia. He is now at Chalmers University of Technology, Gothenburg, Sweden, preparing the establishment of a new business school. He has published widely on many aspects of international business.

Martin Zagler is Assistant Professor at the Vienna University of Economics and Business Administration since 1994. He received the Stephan-Koren Price for the dissertation entitled "Contributions to the Theory of Endogenous Growth under Market Imperfections" and the Theodor-Körner Price for his Contributions to Growth Policy in 1997. His fields of research are Intertemporal Macroeconomics, Endogenous Growth, New Keynesian Economics, Monetary and Exchange Rate Economics.

Laszlo Zsolnai is Director of the Business Ethics Center, Budapest University of Economic Sciences. He is also Visiting Professor of Ethics in the joint MBA Program of the IMC Graduate School of Business, Budapest and the Case Western Reserve University, Cleveland, Ohio. He is the initiator and co-ordinator of the Inter-faculty Group in Business Ethics of the Community of the European Management Schools (CEMS). Dr. Zsolnai has more than 100 publications on interrelated topics of economics, ethics, and human ecology. 


\section{Preface and Acknowledgements}

HEC Foundation has a strong tradition of supporting research programmes in management sciences. The Foundation believes that research in international management is a key factor of success for companies and a key element in management education at HEC School of Management, Paris.

Research programmes of the Foundation associate HEC faculty to corporate members of the Foundation: Adecco, Arthur Andersen, HEC alumni association, Bain \& Company, Banque Nationale de Paris, Bain \& Company, Cartier International, Crédit Lyonnais, EDF/GDF, Ernst \& Young, Casino Group, Gemini Consulting, Hewlett Packard, Lazard Frères \& Cie, L'Oréal, Mars \& Co, Paribas, Pernod Ricard, Price Waterhouse, Procter \& Gamble, Publicis, Schneider, SNCF.

This book is the result of the HEC Foundation research programme on "corporate strategies in emerging countries". The programme covers diverse emerging business environments: Latin America, Asia, Central Europe and CIS. Most of these emerging markets have previously demonstrated a high level of uncertainty: economic fluctuations, social turbulence, political instability, and economic nationalism. However, in spite of recent financial crisis in Mexico (1994), Central and Eastern Europe and Asean (1997), they are still very attractive to foreign direct investors resulting from the development of the private sector, new investment codes, the development of regional trade areas and high growth potential.

International management experts face interesting dilemmas for investigation and action on emerging countries. These economies offer a unique opportunity for companies to quickly build a strong presence in new fast growing markets thanks to privatisation, growth of international trade, 
investment and globalisation. Yet, this opportunity implies risk and flexibility; firms have to adapt their strategic vision, management processes, and human resource policies to local conditions.

Former research has thus helped in identifying common characteristics such as the management of risks, transfer of technology, restructuring of the value chain on a world basis and new patterns of co-operation between local and international companies. Present research focuses on the specificity of economic transition in Central and Eastern Europe and the relationship between the changes in the economic environment and the opportunities for entrepreneurs, strategies and management processes.

The HEC School of Management has a strong established presence in the region since 1989, training MBA students, professors, managers from the Czech Republic, from Hungary, Poland, Lithuania, and Romania as well. This experience contributed to put the research into perspective and to follow the rapid pace of transition.

The HEC Foundation would like to thank all the professors and administrators involved in the development of HEC Central and Eastern Europe Centre who lent to support the research: Jean Klein, Dean of faculty and research, Jean-Marc De Leersnyder, associate Dean for International affairs, Jean-Luc Gulin, deputy General Director, Gilles Laurent, former associate Dean for research, Bérangère Pagès, managing director corporate relations.

The HEC Foundation also benefited from the strong support of the Community of European Management Schools (CEMS) founded in 1988. The CEMS is a European initiative to encourage excellence in management based on a partnership between 50 international companies and 15 leading European management schools.

We are glad to have among our authors professors not only from western schools such as Stockholm School of Economics, U. L. Bocconi (Milan), Vienna University of Economics and Business Administration, but also from the three outstanding Central European institutions that have joined the CEMS in 1998:

- Budapest University of Economic Sciences (Hungary),

- The University of Economics, Prague (Czech Republic),

- Warsaw School of Economics (Poland).

We are also glad to have the contribution of Saul Estrin of London Business School, one of the leading European experts on economic transition. 
The HEC Foundation and the editor would like also to express their special gratitude to:

- Bernard Ramanantsoa, Dean of HEC School of Management, Paris: since the beginning of the programme, his commitment in developing research on transition in Central and Eastern Europe was of immense help.

- François Vachey, Vice President Human Resources of L'Oréal and President of HEC Foundation Development Committee: he initiated the research programme on emerging countries and helped focus our work on key issues for practitioners and researchers.

- Nicole de Fontaines, Secretary General of CEMS and Jaroslava Durcáková, Vice-Rector for International Relations of the University of Economics, Prague: they helped considerably in mobilising researchers of the CEMS network.

HEC Foundation and the editor want also to express their special thanks and congratulation to professor Attila Chikán of Budapest University of Economic Sciences: in July 1997 he took the post of Economics Minister of Hungary's' new government headed by Prime Minister Viktor Orban. Attila Chikán is in favour of liberal economic policy, he wants both to assist foreign investors and help the growth of small and medium enterprises, and he will also prepare Hungarian economy and companies to EU accession. Professors and industrialists of the HEC community wish him the best success.

Antoine Bracchi

Honorary Chairman, Ernst \& Young and Chairman of the Board, HEC Foundation

Paris, November 1998 


\section{Introduction: Organisation of the Book}

Jean-Paul Larçon

HEC School of Management, Paris

Economic transition is part of a transformation process involving major changes at the political, economical, social and psychological level. In less than ten years most countries of Central and Eastern Europe, at the exception of those affected by the war in former Yugoslavia, have re-established a democratic political life, moved rapidly from centrally planned economies to market economies and opened internationally their society and economy. Most of these countries after years of severe economic depression have now recovered and are increasing their participation to European business sphere and world trade.

Privatisation in CEE countries has been the core mechanism of the transformation process; and the transfer of property to private owners radically changed the goals, values and behaviour of all economic agents and decision-makers: employees, pensioners, consumers, companies, stockholders, managers, bankers, municipalities, government agencies.

For some foreign enterprises, CEE countries might be still perceived as a foreign distant, and uncertain environment but for others, ranging from small European family businesses to multinational companies (MNCs), the region in transition is just another facet of the enlarged European domestic market and business environment. Newcomers to the region do not usually face difficulties in operating in this neighbouring cultural environment, but one of 
the major challenge for foreign companies is to adapt their management goals, structures, processes and human resource to rapidly changing local market and local business system. Successful companies in Central Europe have simultaneously been highly responsive to local specific transitional dilemmas and opportunities and integrated their regional approach within a broader framework of a global strategic management perspective.

The objective of this book is to clarify the mechanism of transition in Central and Eastern Europe (CEE) and to highlight its consequences in term of entrepreneurship and corporate behaviour.

Key issues, such as privatisation, development of financial markets, participation in word trade, restructuring industries and companies, foreign direct investment and international joint ventures, are quite similar from one country to another. If problems are similar, solutions are not differing so much even if the pace of transition varies a great deal as well as short-term priorities.

The more the process transition continues, the more similarities and convergence can be find in the evolution of local economic and business environment.

The two first chapters consider the region globally and emphasise two important features:

- First the emergence of an entirely new political and business environment, which has already opened the door for new and successful business strategies of international companies,

- Second the success and limits of privatisation: success by the irreversibility of the reform and the sharing of privatised economy, yet serious limits in term of efficiency. In chapter 2, Estrin argues that mass privatisation did not create the appropriate ownership structures and corporate governance and that it might lead to severe difficulties for efficient restructuring.

New business environment, privatisation, restructuring: in chapter 3 to 9 through analysis these aspects are dealt with in depth, using the most characteristic national examples. CEE countries are not homogeneous: they differ from historical, political, cultural point of views. Some are relatively rich like Slovenia or the Czech Republic, other much poorer like Romania and the Baltic Republics. Four countries are the concentrated on: Czech Republic, Hungary, Poland and Romania, a total population of 83 million inhabitants with three leaders of transition: The Czech Republic, Hungary and Poland and a late comer Romania.

In chapter 3 Nemcova draws the lessons of Czech Privatisation and confirms Estrin quote opinion looking at the positive and negative results of Czech voucher privatisation. She explains the links between voucher privatisation, the power of Investment Funds and the relationship between Funds and 
Czech leading banks. She concludes on political success of privatisation and serious shortcomings in term of restructuring and corporate governance.

In chapter 4, Musilek, discusses the Prague Stock Exchange and a technically well adapted system of trading but which is lacking of serious regulation. The financial market is not yet in a situation to directly serve the needs of Czech companies looking for capital for long term growth.

In chapter 5 Chikán and Czáko concentrate on the issue of restructuring and competitiveness. They point out the four key areas that have influenced competitiveness: changes of the economic mechanism from shortage economy into a market one, the social acceptance of the changes, the characteristics of economic policy and the management of the firms. The authors see the substantial improvement of the performance of Hungarian companies as the result arising from market forces than government economic policy. They also identify managerial skills as a key element of differentiation between Hungarian high and low performing companies.

Continuing in Hungary in chapter 6, Zsolnai probes the ethical fabric of a transforming economy. The social reception of market economy in Hungary as well as the ethical attitudes and values of managers that are still in transition and may involve a lot of ambiguities and ambivalent feelings. The ethical posture of Hungarian companies differs strongly according to two dimensions: the intensity of competition on the local market and the degree of exposure to international competition.

In chapter 7 Romanowska explores the links between economic growth and Foreign Direct Investment (FDI). Poland, the largest economy of the region is now also the leading host country for FDI. Romanowska points out FDI as a key success factor in the transition process thanks to the transfer of resources and technology, the development of exports, and the positive influence on Polish companies' competitiveness.

In chapter 8 Alessandrini investigates the links between social, political and economic transition in Romania. The absence of political stability and a lack of clear direction in term of economic policy have had a very negative impact on Romanian transformation. Real progress in privatisation and in the establishing the legal framework for a market economy is recent and the Romanian government has still to face the difficult challenge of privatising and restructuring large SOEs and public utilities.

Final chapters study three specific aspects of transition: the role SMEs, the strategy of MNCs, and the impact of EU enlargement on business strategies.

Chapter 9 examines the effects of co-operation between small companies of Eastern and Western Europe. Quite spontaneously since 1989 small companies have rediscovered the trade routes of the past. Zagler and Ragacs draw our attention on the role of these co-operations especially in the process of diffusion of innovation and demonstrate their positive effect 
on growth.

Chapter 10 focuses on the behaviour of multinational companies. Swedish MNCs were operating in the region before transition and old relationship helped developing new business. Nordström, Vahlne and Torbacke emphasise the sequential moves of five MNCs in the region and the differentiation of attitudes in term of risk taking. In most cases Eastern Europe strategies integrated into global corporate strategies.

Chapter 11 addresses the issue of EU enlargement. Debié outlines some of the difficulties of the enlargement process due to the of lack of political consensus in the West, ambivalent public support in CEE itself, lack of resources and absence of clear deadlines. Thus, companies operating in CEE still have to face the uncertainties of the agenda and maybe new internal regulatory barriers within $\mathrm{CEE}$ according to the status of the country regarding accession.

In spite of these limitations due to EU governance, the transition and enlargement process are offering an unusual window of opportunity for small and large firms, local and international companies doing business on a pan-European basis. 


\section{ABBREVIATIONS}

$\begin{array}{ll}\text { ASEAN } & \text { Association of South East Asian Nations } \\ \text { CEE } & \text { Central and Eastern Europe } \\ \text { CEFTA } & \text { Central European Free Trade Agreement } \\ \text { CEMS } & \text { Community of European Management Schools } \\ \text { CIS } & \text { Commonwealth of Independent States } \\ \text { CMEA } & \text { Council for Mutual Economic Assistance } \\ \text { COMECON } & \text { See CMEA } \\ \text { CPE } & \text { Centrally Planned Economy } \\ \text { CR } & \text { Czech Republic } \\ \text { CZK } & \text { Czech Koruna } \\ \text { EBRD } & \text { European Bank for Reconstruction and Development } \\ \text { EFTA } & \text { European Free Trade Association } \\ \text { EU } & \text { European Union } \\ \text { FDI } & \text { Foreign Direct Investment } \\ \text { FPN } & \text { National Property Fund (Czech Republic) } \\ \text { GDP } & \text { Gross Domestic Product } \\ \text { GDR } & \text { German Democratic Republic } \\ \text { IMF } & \text { International Monetary Fund } \\ \text { IPFs } & \text { Investment Privatisation Funds (Czech Republic) } \\ \text { JV } & \text { Joint Venture } \\ \text { MBA } & \text { Master in Business Administration } \\ \text { MEBO } & \text { Management and Employee Buy Out } \\ \text { MNCs } & \text { Multinational Companies } \\ \text { NATO } & \text { North Atlantic Treaty Organisation } \\ \text { NIFs } & \text { National Investment Funds (Poland) }\end{array}$


NIS

NGO

OECD

PAIZ

Phare

PLN

PSE

SMEs

SOES

Tacis

UN

UNCTAD

Visegrad Countries

WB

WSE
New Independent States: former republics of the Soviet Union, minus the Baltic States, and Mongolia Non Governmental Organisation

Organisation for European Co-operation and

Development

Polish Agency for Foreign Investment

A EU grant assistance programme for CEE

Polish Zloty

Prague Stock Exchange

Small and Medium Size Enterprises

State-Owned Enterprises

EU grant assistance programme to twelve countries of the former Soviet Union and Mongolia

United Nations

United Nations Conference on Trade and Development

Czech Republic, Hungary, Poland, Slovak Republic and Slovenia

World Bank

Warsaw Stock Exchange 